\title{
Visitor Characteristics and Perceptions: Case of Horton Plains National Park In Sri Lanka
}

\author{
R. M. W. RATHNAYAKE \\ Sabaragamuwa University of Sri Lanka, Sri Lanka. \\ warath1@gmail.com \\ U. A. D. P. GUNAWARDENA \\ University of Sri Jayewardenapura, Sri Lanka. \\ prasanthigunawardena@yahoo.com
}

\begin{abstract}
The aim of this study was to find out visitor characteristics and satisfaction and perceptions of visitors, because park management requires a knowledge of what tourists demand in order that these resources can be optimized. A visitor survey was carried out in Horton Plains National Park (HPNP) to get knowledge on visitor characteristics, satisfaction and their perceptions. The results allowed differentiation of two major types of visitors: generalists and eco-tourists. The visitor survey results imply that HPNP may be the popular tourism destinations for both local and foreign visitors. Majority of foreign visitors (above $50 \%$ ) are Europeans and majority of local visitors (above 40\%) are from the western province. Both local and foreign visitors visit HPNP to see World's End. Generally the satisfaction level among local and foreign visitors at the national park is satisfactory. The majority of visitors are interested in participate in more recreational activities which are not available to have a diverse visitor experience at the park. Some of these visitor services/facilities could be implemented as ecotourism concessions through public-private partnerships. Local visitors mentioned that the tour is worth than that they paid for permits although foreign visitors felt it was not worth what they paid. Marketing of HPNP is not at a satisfactory level and visitors are mainly aware of HPNP from their friends and relatives. This study recommends to Sri Lanka government how to utilize the existing potential in developing ecotourism and maximize the quality of visitor experience at HPNP.
\end{abstract}

Key words: visitor characteristics, national parks, visitor satisfaction 


\section{Introduction}

Protected areas typically promote nature tourism-travel to unspoiled, natural places where people can experience and enjoy nature. Wildlife and ecotourism are some of niche travel forms of nature tourism (Vallentine and Cassells, 1992; Hanneberg, 1994).

Planning for recreational activities in protected areas involves an understanding of multiple and complex factors. Segmentation of the recreational supply and demand in natural areas, together with identification of the main conditioning factors of recreational use, are useful for park management. the recreational supply will be existing visitor services (trails, wildlife safari) and demand will be visitor characteristics (Torbidoni et al., 2005).

Attitudes and perceptions of tourism impacts play an important role in tourism studies. It is said that visitor preferences and suggestions on ongoing recreational activities have been promoted as a basis for sound practice of self-regulation and management intervention in a national park.

With respect to visitor types and activities, a key consideration is the diversity within the ecotourism market. Ecotourists may differ greatly in several aspects, including: distance traveled, length of stay, desired level of physical effort and comfort, importance of nature in trip motivation, level of learning desired, amount of spending, desired activities and personal demographics. Of particular interest, visitor surveys, and anecdotal reports indicate that many ecotourists feel it important for their visit to contribute to conservation and local development (e.g. Eagles 1992). Lindberg (1991) provides a typology of nature /ecotourism types, though many other typologies are possible:

There are several published and unpublished visitor perceptions studies that have been conducted in Sri Lanka. Abeygunewardene and Kodithuwakku (1992), Senarathne et al., (1993), De Silva and Kotagama (1997), Ekanayake and Abeygunawardena (1994), and Rathnayake and Gunewadena (2002 \& 2009) and Marasinghe (2002) have done economic surveys with visitor perception studies. In 2004, Department of Wildlife Conservation also conducted the rapid visitor surveys at pilot project sites including Horton Plains and Kawdulla 
National Parks (Anon., 2004). The common findings in these studies are as follows:

Torbidoni et al. (2005) studied the recreational supply (trails) and demand (visitor characteristics), as well as some other features of a recreational system in the Aigüestortes Estany i de Sant Maurici National Park (Lleida, Spain). Through the application of a Multiple Correspondence Analysis (when dealing with demand) and Cluster Analysis (when dealing with both supply and demand), 4 groups of visitors and 3 groups of trails were identified.

A visitor survey was carried out in Uganda to Kibale National Park in 1992 with the aim of assessing visitor characteristics for proper planning and management of recreational activities, because visitor numbers to Kibble National Park have risen to about 5000 per annum (Anon., 1996).

Visitor surveys are useful in understanding the visitors' expectations, preferences and motivations for recreation opportunities. It is important to understand the visitors' perceptions (as a stakeholder group) in order to determine whether existing visitor facilities are adequate and whether facilities and management actions are necessary for visitor services.

The objectives of present study are as follows:

i. To identify the range of different specialized visitors to the park (i.e bird watchers, leopard watchers)

ii. To identify the activity patterns of visitors within the park

iii. To identify the interpretive needs of visitors

iv. To examine visitor preferences/perceptions for various combinations of social, resource and management conditions.

v. To identify differences among visitor preferences/perceptions for social, resource and management conditions in different recreation settings.

vi. To identify the suggestions of visitors for improved management within the park 


\section{Methodology}

\section{Study Area}

Horton Plains National Park (HPNP) is located approximately between the latitudes $6047^{\prime}$ to $6050^{\prime} \mathrm{N}$ and longitudes $80046^{\prime}$ to 800 50' E (Anon, 1997) (Figure 1). HPNP is situated in the south of Nuwara Eliya district and forms a plateau in the southeastern corner of the main ridge of Sri Lanka's central mountain massif. The HPNP forms the highest tableland in Sri Lanka, with altitude ranging from $2100 \mathrm{~m}$ to $2300 \mathrm{~m}$. The mountain peaks of Kirigalpotta (2389 $\mathrm{m}$ ) and Totupolakanda $(2357 \mathrm{~m})$, the second and third highest mountains in the island, arise from these plains. HPNP received its name in honour of Sri Wilmot Horton, a former British Governor of Ceylon. The 3162 ha area, that forms the national park now, was first established as a Nature Reserve in 1969, and then re-designated as a national park in 1988. The distance from Colombo to HPNP is $225 \mathrm{~km}$.

Figure 1: Map of Horton Plains National Park with view points

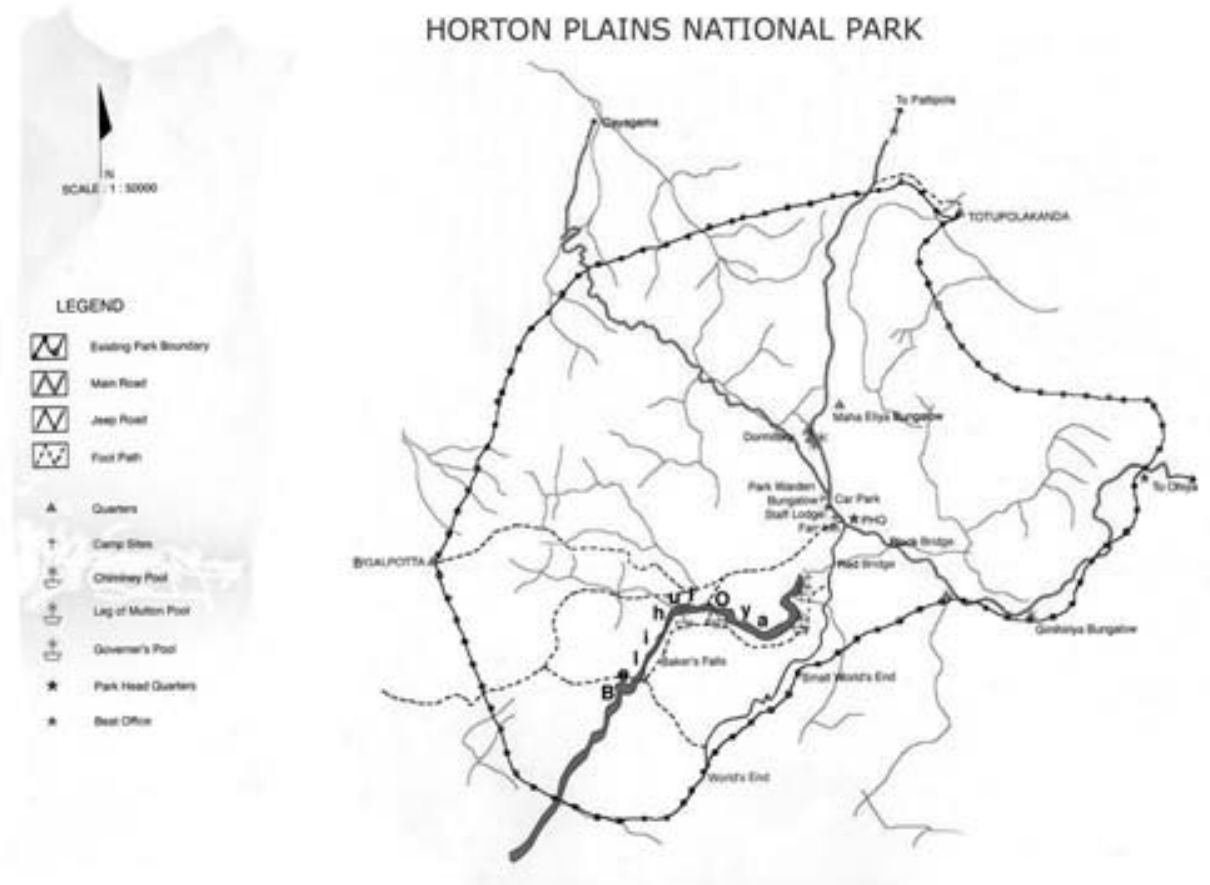


The HPNP has very high visitation, both by locals and foreigners, on account of its varied landscape, salubrious climate, floral and faunal heritage an array of geomorphological attractions. In 2010, HPNP received 167738 visitors including 21846 foreign visitors and earned Rs.69.88 millions. It is the only national park in Sri Lanka where visitors are allowed to walk inside. The main attraction for the tourists is the walk to the World's End, from where a spectacular view of the tea estates and mountain ranges enveloped in mist can be seen. A "look down" from the edge of precipice is an exciting experience in itself. Red bridge, Chimney Pool, Baker's Fall, World's end and Small World's End are major visitor attractive view points in HPNP.

\section{Visitor Survey}

The survey instrument was a questionnaire organized into two sections. The questionnaire consists of 22 sub questions/sections. The part-I of survey questionnaire was designed mainly to obtain information on the visitor profiles i.e. origin of visitors, mode of travel, group size, visitor composition and their age structure. The part II of the questionnaire covered visitation frequency, awareness on parks, reasons for visitation to the parks, visitor experience, rating on visitor attractions in the parks, their willingness to pay for proposed visitor services, attractions to be developed, preferred source of information, perceptions on entrance fees, information sharing language, their recommendations, visitor suggestions, main destination and time allocated for visiting the parks.

The visitors to the park were first divided into two categories i.e. local and foreign visitors. HPNP gets more visitors and it is difficult to interview the all visitors. A preliminary surveys were conducted, and found that at least 100 local visitors and 75 foreign visitors should be interviewed to get diverse perceptions. Therefore only 200 local visitors and 100 foreign visitors were randomly selected and interviewed within one year period. The visitor survey was conducted from $06.30 \mathrm{hrs}$ to $17.00 \mathrm{hrs}$ during public holidays, week ends, and weekdays in proportion to the percentages of visitation to the parks. Visitors were interviewed on site individually. Basically the questionnaire was designed to collect the information directly. 


\section{Results and Discussion}

The answers for most of the questions may vary depending on whether the visitors are local or foreign. As such, it was decided to examine the results separately for local and foreign visitors. Two hundred local visitors were interviewed using the questionnaire and of them only 189 responded for questions, while from 100 foreign visitors interviewed, only 97 visitors answered the questions.

Table 1 shows the summary of visitor characteristics recorded in the visitor survey conducted at HPNP. According to Table 1 majority of local visitors are from Western Province and foreign visitors are from European countries. Majority of both visitors are in the young adult category, and only less amount visit HPNP twice a year.

\section{Table 1: Visitor characteristics at HPNP}

\begin{tabular}{|c|c|c|}
\hline Characteristics & Local visitors & Foreign visitors \\
\hline Origin of visitors & $\begin{array}{l}49.20 \% \text { from Western } \\
\text { Province } \\
14.30 \% \text { from Central } \\
\text { Province } \\
11.40 \% \text { from Southern } \\
\text { Province }\end{array}$ & $55 \%$ from European countries \\
\hline $\begin{array}{l}\text { From where visitors have } \\
\text { traveled to HPNP }\end{array}$ & $\begin{array}{l}72.5 \% \text { from their own } \\
\text { residences }\end{array}$ & $\begin{array}{l}92.80 \% \text { from Guest houses/ } \\
\text { hotels }\end{array}$ \\
\hline Mode of travel to HPNP & $\begin{array}{l}32.30 \% \text { from own vans, } \\
\text { cabs and jeeps }\end{array}$ & $\begin{array}{l}53.60 \% \text { from rented vans, } \\
\text { cabs and jeeps }\end{array}$ \\
\hline $\begin{array}{l}\text { Number of persons in a } \\
\text { group }\end{array}$ & 9.75 & 3.4 \\
\hline $\begin{array}{l}\text { Composition of visitor } \\
\text { group }\end{array}$ & $\begin{array}{l}59.80 \% \text { - relatives, } \\
\text { spouses }\end{array}$ & $61.90 \%$-Friends \\
\hline $\begin{array}{l}\text { Distribution of age } \\
\text { categories }\end{array}$ & $53.60 \%$-young adults & $45.10 \%$ - young adults \\
\hline Frequency of visitation & $\begin{array}{l}22 \%-2 \text { visits per year } \\
40.2 \% \text { - second visit in the } \\
\text { past } 2 \text { years } \\
16.90 \% \text { - third visit in the } \\
\text { past } 2 \text { years }\end{array}$ & $\begin{array}{l}90.70 \%-2 \text { visits per year } \\
7.2 \%-\text { second visit in the } \\
\text { past } 2 \text { years } \\
2.10 \% \text { - third visit in the } \\
\text { past } 2 \text { years }\end{array}$ \\
\hline $\begin{array}{l}\text { How visitors have heard } \\
\text { about HPNP }\end{array}$ & $\begin{array}{l}64 \%-\text { from visitors, } \\
\text { relatives and friends }\end{array}$ & $\begin{array}{l}75.20 \%-\text { from TV, } \\
\text { media and travel brochures }\end{array}$ \\
\hline Reasons for visiting HPNP & $\begin{array}{l}21.70 \% \text { - for World's End } \\
17.50 \% \text { - for Baker's Fall } \\
13.20 \% \text { - for general picnic }\end{array}$ & $\begin{array}{l}26.80 \% \text {-for bird watching } \\
25.80 \% \text {-for Worls's End } \\
10.30 \% \text { - for part of a longer } \\
\text { trip }\end{array}$ \\
\hline
\end{tabular}




\section{Origin of Visitors}

It is noticed that about $49 \%$ of the local visitors travelled to HPNP from Western Province. The lowest visitation was recorded from the Eastern Province. HPNP gets approximately equal numbers of visitors from the Sabaragamuwa and Uva Provinces. The park is situated in the Central Province, and it gets only about $14 \%$ visitors from the same.

Most of local visitors arrived from Western Province because majority of visitors in the Western Province have a high purchasing power, tiredness of living in an artificial environment and requirement of relaxation. In addition, the authorities should closely examine this significant difference of visitation between the Western Province and the other provinces, and should take some action to popularize the park among the other provinces.

HPNP gets the majority of foreign visitors from the European countries. The lowest visitation was recorded from American countries. Other countries also showed that less than $11 \%$ visitation. South East Asian and Australian countries showed the equal visitations.

\section{From Where Visitors have Traveled to Horton Plains National Park}

The visitors were asked from where they travelled to HPNP. More than $72 \%$ of the local visitors have travelled from their home. About 19\% said that they travelled from a hotel or guest house, and another $9 \%$ said that they travelled from other places i.e. relatives' homes, camping huts etc. Majority of local visitors try to cover HPNP within the first day of their trip. About $93 \%$ of the foreign visitors have indicated that they travelled from guest houses or hotels. A few foreign visitors travelled to HPNP either from their homes or other places such as relatives' residences and camping huts.

\section{Mode of travel to the Park}

It could be seen that private vehicles (cars/vans/cabs) are the most frequently used mode of travel among the local visitors. Rental vehicles (cars/vans/cabs) were the next most frequently used mode of travel for locals. Public transport i.e. trains and busses, was used by a few local visitors, because HPNP is an isolated destination and there are no direct public transport to the destination. 
For foreign visitors, rented vehicles (cars/vans/cabs) were the most frequently used mode of travel (54\%), and tourist coach/mini-bus accounted for $25 \%$. Public transport is hardly used by foreign visitors.

\section{Number of Persons in a Group}

The interviewed groups showed that the average number of persons in each local group was 9.75 individuals. For foreign visitors it was 3.4 individuals per group.

\section{Composition of the Visitor Group}

Majority of the local visitors (62\%) were with their friends, and another $23 \%$ were with their spouse and relatives. These figures mean that more than $84.6 \%$ of the local visitors were with their friends, spouses and relatives. In the case of foreign visitors, majority (of about $60 \%$ ) were with their spouses and relatives, and about $24 \%$ were with their friends. This also can be used to promote Horton Plains as a picnic site.

\section{Distribution of Age Groups}

It is clearly seen that young adults of both local and foreign visitors represent the highest percentage (of about $45 \%$ local visitors and $54 \%$ foreign visitors), while middle aged adults represent about $33 \%$ local visitors and $47 \%$ foreign visitors. The local children were about $16 \%$, and that was $4 \%$ for foreign visitors. It can be clearly noticed that the percentage of senior citizens from both groups are very limited. This indicates that World's end trekking was enjoyed only by younger and middle aged crowd.

\section{Frequency of visitation}

About $32 \%$ of local visitors in the sample were on their first trip to the Park. Seventy eight percent of foreign visitors in the sample were on their first trip to the Park. There were $40 \%$ local visitors who had made prior visits to HPNP in the past 2 years. $17 \%$ of them had been to the park twice in the past 2 years. Only $11 \%$ of visitors indicated that they have visited HPNP three times in the past 2 years. No foreign visitors mentioned that they have visited HPNP more than three times in the past two years. 


\section{How Visitors have Heard about Horton Plains National Park}

$64 \%$ of the local visitors heard it from their friends or relatives, and about $21 \%$ from the TV and media. About $15 \%$ visitors heard about HPNP from their schools. Of the foreign visitors, $75 \%$ heard about the Park from their travel brochures or magazines, and $27 \%$ from their friends and relatives.

\section{Table 2: Summary of visitor perceptions at HPNP}

\begin{tabular}{|c|c|c|}
\hline Perceptions & Local visitors & Foreign visitors \\
\hline Reasons for visiting HPNP & $\begin{array}{l}21.70 \% \text { - for World's End } \\
17.50 \% \text { - for Baker's Fall } \\
13.20 \% \text { - for general picnic }\end{array}$ & $\begin{array}{l}26.80 \% \text {-for bird watching } \\
25.80 \% \text {-for Worls's End } \\
10.30 \% \text { - for part of a longer } \\
\text { trip }\end{array}$ \\
\hline $\begin{array}{l}\text { Satisfaction with the activities } \\
\text { experienced in the park }\end{array}$ & $\begin{array}{l}\text { The most satisfaction activities } \\
\text { are } \\
\text { i. Baker's Fall viewing } \\
\text { ii. Trecking to World's End } \\
\text { iii. Viewing scenary }\end{array}$ & $\begin{array}{l}\text { The most satisfaction activities } \\
\text { are } \\
\text { i. Baker's Fall viewing } \\
\text { ii. Viewing scenary } \\
\text { iii. Trecking to World's End }\end{array}$ \\
\hline Rating of visitor attraction & $\begin{array}{l}\text { World's End } \\
\text { Scenary Landscape } \\
\text { Baker's Fall }\end{array}$ & $\begin{array}{l}\text { Scenary Landscape } \\
\text { Baker's Fall } \\
\text { World's End }\end{array}$ \\
\hline $\begin{array}{l}\text { Willingness to pay for some } \\
\text { facilities/services }\end{array}$ & $\begin{array}{l}26 \% \text { - Hiking to Kirigalpotta } \\
\text { with a guide } \\
16.4 \% \text {-Renting camping } \\
\text { equipments } \\
18 \% \text { - Bicycle for hire }\end{array}$ & $\begin{array}{l}32 \% \text { - Bicycle for hire } \\
19.60 \% \text {-Guide service along the } \\
\text { trai } \\
17.50 \% \text {-Hiking to Kirigalpotta } \\
\text { with a guide }\end{array}$ \\
\hline $\begin{array}{l}\text { Rating for importance of } \\
\text { some visitor attractions }\end{array}$ & $\begin{array}{l}\text { Vehicle park } \\
\text { Overall cleanliness } \\
\text { Access to information about } \\
\text { HPNP }\end{array}$ & $\begin{array}{l}\text { Vehicle park } \\
\text { Overall cleanliness } \\
\text { Entrance Procedure }\end{array}$ \\
\hline $\begin{array}{l}\text { Preferred sources of visitor } \\
\text { information }\end{array}$ & $\begin{array}{l}\text { Maps/Animated map method } \\
\text { Knowledgeable guides } \\
\text { Visitor centre exhibits Films }\end{array}$ & $\begin{array}{l}\text { Knowledgeable guides } \\
\text { Maps/Animated map method } \\
\text { Guide Books }\end{array}$ \\
\hline Price of the ticket & Highly satisfied & Not satisfied \\
\hline $\begin{array}{l}\text { Preferred language for } \\
\text { information about the park }\end{array}$ & $65 \%$ - two or more languages & $57.7 \%$-Two or more languages \\
\hline $\begin{array}{l}\text { Recommending the HPNP to } \\
\text { friends }\end{array}$ & $80.40 \%$-Highly recommended & $50.50 \%$-Highly recommended \\
\hline $\begin{array}{l}\text { Suggestions of visitors to } \\
\text { improve visitor satisfaction }\end{array}$ & $\begin{array}{l}31.20 \% \text { - Developing trail } \\
12.20 \% \text { - More signages } \\
12.20 \% \text { - Clean toilets }\end{array}$ & $\begin{array}{l}34 \% \text { - Developing trail } \\
20.60 \% \text { - Good guides } \\
14.40 \% \text { - Medical facilities } \\
14.4 \% \text { - Clean toilets }\end{array}$ \\
\hline Main destination of the trip & $\begin{array}{l}34.40 \% \text { - NuwaraEliya } \\
32.30 \% \text { - HPNP } \\
15.30 \% \text { - Others }\end{array}$ & $\begin{array}{l}52.60 \%-\text { NuwaraEliya } \\
23.70 \%-\text { HPNP } \\
16.50 \%-K a n d y\end{array}$ \\
\hline Duration of the trips & $\begin{array}{l}48.10 \% \text { of visitors }-<1 \text { day } \\
33.30 \% \text { of visitors }-1-2 \text { days }\end{array}$ & $\begin{array}{l}55.70 \% \text { of visitors }-1-2 \text { days } \\
23 \% \text { of visitors }-<1 \text { day } \\
20.60 \% \text { of visitors }-3-4 \text { days }\end{array}$ \\
\hline Time spent at HPNP & $\begin{array}{l}68.30 \% \text { of visitors- } 4-6 \text { hours } \\
22.20 \% \text { of visitors-Less than } \\
4 \text { hours }\end{array}$ & $\begin{array}{l}55.70 \% \text { of visitors- } 4-6 \text { hours } \\
38.10 \% \text { of visitors-Less than } \\
4 \text { hours }\end{array}$ \\
\hline $\begin{array}{l}\text { The place where visitors stay } \\
\text { tonight }\end{array}$ & $34.40 \%$ of visitors-NuwaEliya & $75 \%$ of visitors- NuwaEliya \\
\hline
\end{tabular}


Table 2 shows the summary of visitor perceptions recorded in the visitor survey conducted at HPNP. These perceptions are on resons for visiting HPNP, satisfaction on visitor activities, visitor attractions, their willingness to pay for some visitor facilities, price of a ticket, prefferred language for obtaining information, suggestions for improvement etc.

\section{Reasons for visiting Horton Plains}

The visitors were asked to rank the 3 main reasons that made them come to HPNP. "Visit the World's End" was the main reason (rank 1) of majority $(22 \%)$ of the local visitors. The main reason of another $18 \%$ was to visit the Baker's Fall, and another $13 \%$ as a general picnic, about $68 \%$ of the local visitors have a desire to experience nature and scenery. The authorities should make a note of this when planning future activities of the park. The main reason of foreign visitors to visit HPNP was either to watch birds (27\%) or to visit World's End (26\%). Another $10 \%$ visit as a part of a long trip.

\section{Satisfaction with the activities experienced in the Park}

The visitors were asked to describe the satisfaction of certain activities they experienced during their visit. The levels of satisfaction were categorized as "Very satisfied" (score 4), " satisfied" (score 3), "Fairly satisfied" (score 2), and "Hardly satisfied" (score 1). Here, "Not sure" and "Did not do" categories were discarded. Generally the satisfaction level is above hardly satisfied for all the activities. "Baker's Fall viewing" had the highest average satisfaction level of above 3.6 (with $4=$ very satisfied) for both local and foreign visitors. "Viewing scenery" had the next highest average value of above 3.4 (with $4=$ very satisfied) for both groups. This means that they were highly pleased with the nature and sceneries in HPNP. The satisfaction level of foreign visitors on "Trek to World's End" was also high 3.1.

It can also be seen from the figure that both the local and foreign visitors were below the fairly satisfied level with "Bird watching" (the lowest average of 1.9 for locals and 1.4 for foreign). It is also noted that the satisfaction level for "Watching wildlife" is also comparatively low (2.1 for locals and 2.4 for foreign). These results might provide a valid representation of the general visitors' response to HPNP. However, due to the sampling strategy it is unlikely that they 
captured more specialized birders and wildlife enthusiasts who tend not to visit World's End and also to visit very early in the morning or late in the evening. A different sampling strategy is required to elicit their response to this question. The satisfaction level for "Cafeteria" is above 3.0 (3.1 for local and 3.2 for foreign), which suggests that the cafeterias are at satisfactory levels.

\section{Rating of Visitor Attractions}

The visitors were asked to rate the visitor attractions at HPNP during their visit. The levels of attractions were categorized as "Highly attractive" (score 4), "Attractive" (score 3), "Fairly attractive" (score 2), and "Hardly attractive" (score 1). Here, the response category "Not sure" was discarded. The average level of attraction of local and foreign visitors for different features of the park. For both local and foreign visitors, the most attractive features (value of rating above 3.6 with $4=$ Highly attractive) in HPNP were "World's End" and "Scenery/ landscape". The local visitors have given the highest rating (3.7) for "World's End" in Horton Plains, whereas foreign visitors have given the highest rating for "Scenery/landscape".

Of all the features considered, the attraction rate is generally high. However, the least attractive features in HPNP were "peace and quite" (average rating of 1.6 and 2.2 for local and foreign visitors with $2=$ Fairly satisfied). The least attraction levels were recorded for trained staff (rating of 1.7 and 1.6 for local and foreign visitors). Local visitors were above hardly satisfied level with the camping facility, and foreign visitors have not mentioned camping facility among their attraction camping facility, because they do not experience camping at HPNP.

\section{Willingness to pay for some facilities/services}

The visitors were asked whether they are willing to pay (or not willing) an additional fee for each of the following facilities/services.

$\square \quad$ A guided mountain hike

Majority (about $27 \%$ ) of the local visitors were willing to pay for a guided mountain hike to Kirigalpoththa or Totupola Kanda. Although the majority of the foreign visitors were not willing, $18 \%$ of them were willing to pay for this 
service and it showed that the foreign visitors' second choice is a guided mountain hike. The percentage of willingness to pay for a guided mountain hike has a demand which is significant enough for the authorities to pay a special attention to introduce this service.

$\square$ Bicycles for hire

Eighteen percent of local visitors were willing to pay an additional fee for "Bicycles for hire". The foreign visitors mentioned that their highest preference $(32 \%)$ on willingness to pay on "Bicycles for hire". Generally, the percentages of willingness to pay for hiring bicycles are also sufficient to introduce this service. Bicycles for hire could be considered as a concession for private public partnerships.

$\square$ A Guide service along the trail

About $20 \%$ of the foreign visitors were willing to pay for a Guide service along the trail on the commonly used trails as their third preference. In addition, $13 \%$ of the local visitors were willing to pay for this service. Hence, the authorities should consider introducing this service at least for foreign visitors.

$\square$ Renting camping equipments

Sixteen percent of the local and $5 \%$ of the foreign visitors were willing to pay for this. The foreign visitors were not familiar with camping experience in Sri Lanka and that was why their preference was very low on this aspect. Therefore the authorities should consider introducing this service at least for local visitors first.

$\square$ Dormitory accommodation

It can be seen that $11 \%$ of the local visitors were willing to pay for dormitory accommodation, although a few foreign visitors were willing to pay for dormitory accommodation. During the study period the dormitory was under construction and foreign visitors were not aware of dormitory facilities and that may have led to low level of willingness to pay for dormitory accommodation. Generally these figures suggest that at least $11 \%$ of local visitors are prepared to pay for this service as their 4 th preference and hence the authorities should pay an attention to introduce this service. 
$\square$ Interpretive talks

About $10 \%$ of the local visitors were willing to pay for a interpretive talks in the national park. At the moment there are no interpretive officers or proper interpretive talks conducted on natural history or Horton Plains National Park. This gap was clearly identified by foreign visitors and mentioned it as their third highest preference for willingness to pay. Therefore there is a demand for interpretive talks at the visitor centre and it is significant enough for the authorities to pay a special attention to introduce this service.

\section{$\square$ Clean Toilet Facilities}

Considerable amount of foreign and local visitors are willing to pay for clean toilet facilities. The cleaning part of existing toilets could be contracted out and the contractor could be asked to fix a ticket price for toilet use. There is a potential to maintain the toilets as paying toilets. This could be introduced to HPNP.

\section{Rating for Importance of Some Visitor Attractions to be Improved at Horton Plains National Park}

The visitors were asked to rate the following aspects at HPNP during their visit i.e. State of Access Road, Ease of locating Horton Plains National Park, Entrance Procedure, Access to information about HPNP, Camping facilities, Dormitory Facilities, Maintenance of Trails,Availability of drinking water and resting places, Overall cleanliness, Garbage disposal facilities, Clean toilet facilities,Cooperation of park staff, Directional signages, Interpretive signages along the trail, Vehicle park, Circuit bungalow accommodation. The levels of ratings were categorised as "Excellent" (score 4), "Good" (score 3), "Fair" (score 2), and "Poor" (score 1). The responses for the question on "vehicle park" got the highest rating of above 3.8 for both local and foreign visitors. Next highest score was recorded for overall cleanness with a rating of above 3.7.

"Access to information about HPNP" (rating of 3.1 for local visitors and 2.9 for foreign visitors which are above Good and Fair respectively). "Garbage disposal facilities (rating of 2.9 for local visitors and 3.1 for foreign visitors which are at Good level)." and "Cooperation of staff (rating of 3.2 for local visitors and 2.9 for foreign visitors which are Good level)" were given the next 
highest average rating ( $3.0=$ Good) by both local and foreign visitors suggesting that both group of visitors are pleased with above aspects.

The local and foreign visitors have also given the lowest ratings (about 1) for "Availability of drinking water" and resting places" and "Maintenance of Trails". The aspect "entrance procedures" received the score level above 2 from both local and foreign visitors. Both local and foreign visitors did not answer the question on dormitory facilities because during the study period dormitory have not been opened for the visitors due to the on going construction activities. Foreign visitors have given a low ratings for camping facility which is poor (1), because only few foreign visitors were familiar with camping facilities in the HPNP.

\section{Preferred Sources of Visitor Information}

The visitors were asked about the sources of visitor information they prefer at the entrance. They were allowed to state more than one preferred sources of information (maximum of 3), and therefore, the total number of responses here exceeds the number of visitors who responded for this question. Majority of the local visitors prefer "Maps/Animated map models" (20\%), "Knowledgeable guides" (18\%), and "Visitor centre exhibits" (15\%) at the entrance. Majority of the foreign visitors also prefer "Knowledgeable guides" (22\%), "Maps/ Animated map method" (21\%), and "Guide books" (20\%). When considering both local and foreign visitors, there is an overall demand for "Maps/Animated map models" and "Knowledgeable guides". It should also be noted that there is some demand for "written materials i.e. brochures, guide books etc. In general, there is demand for "Knowledgeable guides/staff" to be made available to tour groups. This is very important and it could be easily introduced to the park.

\section{Price of the Ticket}

The visitors were asked questions on price of a permit. For those visitors who said that either it was worth more than they paid or it was not worth what they paid, were asked what should be the correct price of the ticket. Majority of local visitors mentioned that either it was just above I paid or it was worth that 
I paid for the permit. Based on that the average of their quoted ticket prices is Rs. 58.50, and it is above the current price of the permit. The average price of the ticket of the foreign visitors was US\$ 10.2, which is nearly two third of the current price (US\$14/-) of the ticket. Regarding the rating of overall visit in relation to the entrance fees, only $14 \%$ of foreign visitors felt that it was worth more than what they have paid, and another $12 \%$ felt that it was worth. The authorities should pay a special attention to the fact that $35 \%$ of the foreign visitors felt it was not worth for what they have paid. The foreign visitors were of the view that the average price of the ticket should be US\$10.2 which is less than the current price of the ticket. This is something that the authorities must consider seriously, where they must compare the facilities given for the foreign visitors with the amount being charged.

\section{Preferred Language for Information about the Park}

The visitors were asked to state what language/s would they prefer to get information about HPNP. Here, the visitors were given 4 options (multiple responses) to state their language preferences. As such, the total number of responses for this question is more than the number of visitors who responded for this question. There were 189 responses from local visitors, and 97 responses from foreign visitors. Majority of the local visitors (66\%) prefer information in two or more languages. Of the local visitors, another 14\% prefer Sinhala only, about $11 \%$ prefer English only, and 10\% prefer Tamil. Of the foreign visitors, majority (58\%) prefer obtaining information in two or more languages, while about $20 \%$ in German, and about $12 \%$ in French. The majority of visitors were willing to obtain the information in more than two languages. The wayside and visitor centre exhibits for interpreting the fauna and flora, natural environment and threats to natural environment have been designed in three languages which is according to the language policy of interpretation in the ecotourism visitor services policy drafted by the Department of Wildlife Conservation. It is also important that the available leaflets, brochures and posters be prepared in at least three languages i.e. Sinhala, Tamil and English. 


\section{Whether Recommending the Horton Plains National Park to Friends}

The visitors were asked whether they would tell their friends to visit the Horton Plains Park. The majority of local visitors $(80 \%)$ said that they would recommend their friends to visit the park. About $51 \%$ foreign visitors mentioned that they would recommend their friends to visit Horton Plains National Park. A few visitors (both local and foreign) mentioned that they would not recommend their friends to visit Horton Plains. While asking the reason why, they did not recommend due to the reasons of being expensive and difficulties to walk along the nature trails.

\section{Suggestions to Improve Visitor Satisfaction}

The visitors were asked "what three things do you most want changed to improve visitor satisfaction at HPNP". There were 177 responses, and the highest percentage of $31 \%$ of them was for the "development of trails", and the next highest percentage of $12 \%$ was for the improvements of "clean toilets and drinking water facilities". Further, they have mentioned about "need of medical facilities" (10\%). Thirty four percent foreign visitors indicated that the nature trail to be improved. Another $21 \%$ mentioned that the "need of good guides in the HPNP. Fourteen percent foreign visitors indicated the requirement of medical and clean toilet facilities.

\section{Main Destination of the Trip}

The visitors were asked about the main destination of the current trip. The main destinations of majority of the local visitors was either Nuwara Eliya (about $34 \%)$, or Horton Plains National Park (32\%). When examining the figures carefully, it can be seen that the destination of more than $67 \%$ of the local visitors was the areas close to Horton Plains Park. The main destination of the majority $(53 \%)$ of the foreign visitors was Nuwara Eliya or HPNP.

\section{Duration of the Trip}

The visitors were asked "how many days did they plan to spend or are they planning to spend on this trip". More than $48 \%$ of the local visitors like to spend 1 - 2 days on this trip. The plan of about $33 \%$ of them was on 1 day, 
$20 \%, 3-4$ days and about $4 \%$ more than 5 days. Of the foreign visitors, the plan of $56 \%$ of them was to spend 1 to 2 days around HPNP and Nuwara Eliya, Only about $24 \%$ of foreign visitors were planning to spend less than one day for HPNP.

\section{Time Spent at the Park Site}

Majority of local visitors (68\%) and foreign visitors (56\%) spent 4-6 hours at the HPNP. Twenty two percent of local visitors and $38 \%$ of foreign visitors spent less than 4 hours at the park. Comparatively lesser number of visitors spent more than 6 hours. Therefore, visitors are willing to spend more time at HPNP, and that indicates there should be visitor facilities such as resting places and toilet facilities along the nature trail.

\section{The Place Where Visitors Stay Tonight}

The visitors were asked where they would be staying tonight. More than $34 \%$ of the local visitors may stay at Nuwara Eliya, another $22 \%$ local visitors at Kandy. The other category was $33 \%$ and those respondents mentioned different districts for their stay to night. Of all the foreign visitors, $75 \%$ of visitors stayed at Nuwara-Eliya. Another $11 \%$ of visitors were to stay at Kandy. This indicated both local and foreign visitors have chosen either Nuwara Eliya or Kandy to stay tonight.

\section{Conclusion}

The visitor survey results at both study sites shows that the ecotourism potential is under utilized and only the national visitor services and tourism activities are going on. New visitor services, facilities and activities have to be introduced and it may lead to ecotourism promotion at each national park. The Department of Wildlife Conservation should conduct well-targeted and planned promotional programmes about Sri Lanka's wildlife parks in European countries (especially UK) and Asian and South East Asian countries to attract more visitors to Sri Lanka. 
During the survey period, visitors from Western Province were significantly high, and very low visitation was recorded from rest of the country. Department of Wildlife Conservation (DWC) may take productive steps to popularize the parks among people from the other provinces too.

There should be ongoing training programs to train the guides in the wildlife parks to improve their quality in general, especially language skills and subject knowledge. It is important that the parks have guides who can communicate in German and French languages. Pre booking systems for wildlife parks, Internet based booking facilities, Internet based promotional programs are recommended to attract more foreign visitors. At the visitor centres of both parks, there should be information on wildlife to obtain especially written material, knowledgeable guides, animated maps/models and presentations.

The survey results have shown that visitors are willing to pay separately for certain facilities/services that are specific to each park. The DWC should take the maximum use of those opportunities to increase the income while providing a good service. The foreign visitors feel that the entrance fee of the parks should be reduced, but the local visitors feel the fee could be increased a little. Therefore, the authorities should revise the entrance-fee structure of the wildlife parks.

\section{References}

Abeygunawardena, P. \& Kodithuwakku, K.A.S.S. (1993). Factors influencing the Appreciation of Benefits Provided by Peradeniya Botanic Garden: Willingness to Pay Approach. Tropical Agricultural Research. 5:149-168.

Anon. (1996). Visitor characteristics and attitudes towards Kibale National Park, Uganda. Tourism Management .Volume: 17, Issue: 7, Publisher: Elsevier, Pages: 495 505

Anon, (1997). Wetland site report and Conservation management plan for Horton Plains National Park, Central Environmental Authority, Sri Lanka.

Anon., (2004). Visitor survey report for pilot project sites under PAM \& WCP. Department of Wildlife Conservation, Sri Lanka 
De Silva, K.A.I.D \& Kotagama, H.B. (1997). An Optimal Fee for Entrance to Udawalawe National Park: An Assessment. Tropical Agricultural Research. 9: 317-329.

Eagles, P. F. J. (1992). The travel motivations of Canadian ecotourists. In Journal of Travel Research, 31 (Fall): 3-7.

Ekanayake, E.R.M. \& Abeygunawardena P. (1994). Valuation of Conservation Commodity of the Sinharaja Forest: Towards Total Economic Valve. Sri Lanka Journal of Agricultural Economics, 2:1

Hannberg, G, P. (1994). Ecotourism or Ecoterrorism? Enviro, No. 17, 2-5.

Jayaratne C. T. and Gunawardena U. A. D. P. (2004). Estimation of local recreational value of Hakgala botanical garden, In Proceedings of Ninth International Forestry and Environment Symposium of the Department of Forestry and Environmental Science, University of Sri Jayewardenepura, Sri Lanka.

Kariyawasam, D. (1992). Using the Travel Cost Method for Assessing Recreational Benefits in a Biosphere Reserve, The Sri Lanka Forester. XX(3\&4):1 1-18

Lindberg, K. (1991). Policies for maximizing nature tourism's ecological and environmental benefits. Washington, DC: World Resources Institute.

Marasinghe, M.S.L.R.P, (2002). An Estimate of the Recreational Value of Yala National Park. The Department of National Planning, Ministry of Policy Development and Implementation., Colombo, Sri Lanka

Rathnayake R M W \& Gunawardena U. A. D. P. (2002). Estimation of recreational value of the Wasgamuwa National Park, In Proceedings of International Conference on relating the environment to regional development organized by USJ/SIDA/ SAREC Research Co-operation Project and Ministry of Environment and Natural Resources, Colombo, Sri Lanka,

Rathnayake R M W and Gunawardena U. A. D. P. (2009). Estimation of recreational value of the Kawdulla National Park. Sri Lanka Journal of Real Estate. 2009:September 
Senarathne, D.M.A.H., Abeygunawardena P. \& Kodituwakku, K.A.S.S. (1993). Factors influencing the Appreciation of Benefit Provided by Peradeniya Botanic Garden. Willingness to Pay Approach. Tropical Agricultural Research. 5:149-168

Torbidoni, E. I F., Grau H. R. and Camps, A.(2005). Trail Preferences and Visitor Characteristics in Aigüestortes i Estany de Sant Maurici National Park, Spain. Mountain Research and Development 25(1):51-59. 2005

Valentine, P.S. and Cassells, D.S. (1992). Recreation management issues in tropical rainforests. Seminar on Executive Development, June 1-26, Institute for Tourism, Hawaii, 9-14. 